\title{
Dampak Minyak Dunia, Energi Terbarukan, dan Kebijakan Moneter Terhadap Laju Pertumbuhan Ekonomi di Indonesia Tahun 1987-2019
}

\author{
(The Effect of World Oil, Renewable Energy, and Monetary Policy on The Economic Growth Rate \\ in Indonesia 1987-2019)
}

\author{
Andi Nur Fauziyah Syafriany ${ }^{1 *}$, Ika Yuni Wulansari ${ }^{2}$ \\ ${ }^{1,2}$ Politeknik Statistika STIS \\ Jalan Otto Iskandardinata Raya No. 64 C, Bidara Cina, Jatinegara, Jakarta Timur 13330 \\ E-mail: 111810166@stis.ac.id
}

\begin{abstract}
ABSTRAK
Salah satu indikator yang bisa digunakan untuk mengetahui kemajuan suatu negara bisa dengan menggunakan indikator laju pertumbuhan ekonomi. Indonesia sebagai salah satu negara yang sedang berkembang memiliki laju pertumbuhan ekonomi yang mengalami fluktuasi dari tahun ke tahun. Hal ini bisa dipengaruhi oleh beberapa faktor dari berbagai aspek kehidupan seperti energi, faktor produksi, dan moneter. Oleh karena itu, penelitian ini bertujuan untuk mengetahui gambaran laju pertumbuhan ekonomi Indonesia 1987-2019 dan faktor-faktor yang memengaruhi laju pertumbuhan ekonomi Indonesia dalam jangka panjang dan jangka pendek. Penelitian ini menggunakan metode Error Correction Mechanism. Hasil penelitian menunjukkan bahwa produksi minyak dunia, nilai tukar Rupiah terhadap US Dollar, dan suku bunga berpengaruh signifikan terhadap laju pertumbuhan ekonomi Indonesia dalam jangka panjang. Selain itu, persentase Pembentukan Modal Tetap Bruto terhadap total PDB pengeluaran Indonesia, nilai tukar Rupiah ke US Dollar, suku bunga, dan Error Correction Term (ECT) berpengaruh signifikan terhadap laju pertumbuhan ekonomi Indonesia dalam jangka pendek.
\end{abstract}

Kata kunci: minyak dunia, energi terbarukan, kebijakan moneter, laju pertumbuhan ekonomi, Error Correction Mechanism

\section{ABSTRACT}

One of the indicators that can determine the progress of a country is economic growth rate. Indonesia as one of developing country has a volatile economic growth rate from year to year. This thing can be affect by some factors in some aspects of life such energy, production factors, and monetary. Therefore, the goal of this study is know the general description of Indonesia's economic growth rate 1987-2019 and the factors that can affect Indonesia's economic growth rate, both in the long and short term. This study use Error Correction Mechanism method. The result of this study is world oil production, exchange rate of Rupiah to United Stated Dollar, and interest rate significantly influenced Indonesia economic growth rate in long term. Besides that, gross fixed capital formation, exchange rate of Rupiah to United Stated Dollar, interest rate, and Error Correction Term (ECT) significantly influenced Indonesia economic growth in short term.

Keywords: world oil, renewable energy, monetary policy, the rate of economic growth, Error Correction Mechanism

\section{PENDAHULUAN}

Pertumbuhan Ekonomi menjadi hal yang tentunya sangat menarik untuk diperbincangkan. Hal ini dikarenakan maju atau tidaknya suatu negara bisa dilihat bagaimana pertumbuhan ekonominya dari tahun ke tahun. Menurut Sadono Sukirno (2016), pertumbuhan ekonomi dapat didefinisikan sebagai perkembangan kegiatan dalam perekonomian yang menyebabkan barang dan jasa yang diproduksinya dalam masyarakat bertambah. Dalam menghitung pertumbuhan ekonomi, kita bisa menggunakan Produk Domestik Bruto (PDB). Menuru Sadono Sukirno (2016), PDB dapat digunakan untuk menilai prestasi pertumbuhan ekonomi dan menentukan tingkat kemakmuran masyarakat dan perkembangannya sehingga perhitungan pertumbuhan ekonomi secara langsung dapat dihitung dari PDB Riil yang tersedia. PDB Riil menurut Mankiw (2003) merupakan PDB atas dasar harga konstan yang dihitung berdasarkan faktor produksi terhadap suatu tingkat harga tertentu dalam satu tahun tertentu (tahun dasar). PDB Riil dinilai sebagai indikator perekonomian yang baik karena PDB Riil ini menghitung output barang dan jasa perekonomian dan tidak dipengaruhi oleh harga sehingga PDB Riil dinilai mampu memberikan ukuran kemakmuran ekonomi yang lebih baik dibandingkan PDB Nominal. PDB Riil bisa menghitung langsung bagaimana laju dari pertumbuhan ekonomi.

Dengan adanya laju pertumbuhan ekonomi yang terjadi dalam suatu negara, hal yang bisa diketahui ialah bagaimana perkembangan kemakmuran dan kesejahteraan masyarakat dalam negara tersebut. Selain itu, laju 
pertumbuhan ekonomi juga bisa dipengaruhi oleh berbagai aspek yang berhubungan langsung dalam kehidupan kita. Beberapa aspek yang diperkirakan memengaruhi laju pertumbuhan ekonomi ialah aspek energi, faktor produksi, dan indikator moneter. Adapun aspek faktor produksi yang diperkirakan memengaruhi laju pertumbuhan ekonomi ialah PMTB dan TPAK. Menurut SNA 2008, PMTB ialah pengeluaran modal untuk melakukan kegiatan produksi barang dan jasa sehingga bisa menambat output dari produksi tersebut diperkirakan memengaruhi laju pertumbuhan ekonomi dikarenakan PMTB termasuk salah satu indikator yang dihitung dalam PDB pengeluaran. Penelitian yang dilakukan oleh Gulzar Ali (2015) menyatakan bahwa PMTB memiliki pengaruh signifikan terhadap laju pertumbuhan ekonomi. Hal ini dikarenakan PMTB merupakan ukuran penting dan dihitung dalam mengukur Produk Domestik Bruto (PDB) sehingga PMTB ini juga merupakan elemen penting dalam pengukuran laju pertumbuhan ekonomi. Menurut Menurut Sadono Sukirno (2016), Tingkat Partisipasi Angkatan Kerja (TPAK) merupakan ialah perbandingan antara angkatan kerja dengan penduduk usia kerja yang dinyatakan dalam persen. Penelitian yang dilakukan oleh Zhao et al (2016) menyatakan bahwa terdapat hubungan jangka panjang dan elastisitas antara pertumbuhan ekonomi dan tenaga kerja.

Aspek indikator moneter yang diperkirakan laju pertumbuhan ekonomi ialah nilai tukar Rupiah terhadap Dollar Amerika Serikat dan suku bunga. Menurut Nopirin (2018), nilai tukar atau kurs ialah harga atau nilai mata uang suatu negara dinyatakan dalam nilai mata uang asing. Naik turunnya nilai tukar dari suatu periode ke periode lainnya bergantung pada kondisi perekonomian di suatu negara. Penelitian yang dilakukan oleh Putra (2016) menyatakan bahwa nilai tukar berpengaruh terhadap pertumbuhan ekonomi. Hal ini dikarenakan nilai tukar bisa mengalami depresiasi maka harga barang luar negeri akan menjadi mahal sehingga bisa berpengaruh pada persediaan bahan baku impor yang digunakan dalam proses produksi. Indikator moneter lainnya seperti suku bunga diperkirakan bisa memengaruhi laju pertumbuhan ekonomi. Penelitian yang dilakukan oleh Saputri (2018) menyatakan bahwa suku bunga berpengaruh negatif signifikan terhadap pertumbuhan ekonomi dalam jangka panjang dan jangka pendek.

Dalam penelitian ini, aspek energi yang diperkirakan memengaruhi laju pertumbuhan ekonomi ialah minyak dunia dan energi terbarukan. Penelitian yang dilakukan oleh Dwi dkk (2016) menyatakan bahwa minyak dunia berpengaruh signifikan terhadap laju pertumbuhan ekoomi karena minyak dunia digunakan sebagai sumber energi utama untuk menjalankan kegiatan produksi di sebuah negara. Penelitian yang dilakukan oleh Can dan Korkmaz (2017) menyatakan bahwa energi terbarukan signifikan terhadap pertumbuhan ekonomi (pada studi kasus di Bulgaria) dikarenakan energi terbarukan bisa menggantikan ketergantungan pada minyak dunia sebagai sumber energi kegiatan produksi dan untuk mengurangi pencemaran lingkungan.

Konsumsi energi terbarukan di negara Indonesia sendiri hanya berkisar sebesar 1\%-2\% dari total keseluruhan konsumsi energi di Indonesia. Oleh karena itu, penelitian ini bertujuan untuk melihat apakah konsumsi energi terbarukan berpengaruh terhadap laju pertumbuhan ekonomi di Indonesia. Selain itu, penelitian ini juga bertujuan untuk mengetahui gambaran umum laju pertumbuhan ekonomi Indonesia dan untuk mengetahui faktor-faktor yang memengaruhi laju pertumbuhan ekonomi di Indonesia tahun 1987 hingga tahun 2019 baik dalam jangka panjang maupun jangka pendek.

\section{METODE}

Metode analisis yang digunakan dalam penelitian ini ialah analisis deskriptif dan analisis inferensia. Analisis deskriptif bertujuan untuk melihat gambaran laju pertumbuhan ekonomi di Indonesia. Analisis inferensia menggunakan metode Error Correction Mechanism (ECM) yang bertujuan untuk menjawab tujuan penelitian, yaitu untuk melihat faktor-faktor apa saja yang memengaruhi laju pertumbuhan ekonomi di Indonesia tahun 1987-2019 dalam jangka panjang dan jangka pendek. Sebelum melangkah pada tahapan metode ECM, terlebih dahulu menghitung laju pertumbuhan ekonomi Indonesia tahun 1987-2019. Adapun rumus untuk menentukan laju pertumbuhan ekonomi ialah sebagai berikut:

$$
L P E_{t}=\frac{P D B R i i l_{t}-P D B R i i l_{t-1}}{P D B R i l_{t-1}}
$$

Sehingga laju pertumbuhan ekonomi ini memiliki nilai dalam bentuk persen.

di mana:

$L P E_{t}=$ Laju Pertumbuhan Ekonomi tahun $\mathrm{t}$ (saat ini)

$P D B$ Riil $_{t}=$ PDB Riil tahun $\mathrm{t}$ (saat ini)

$P D B$ Riil $_{t-1}=$ PDB Riil tahun sebelumnya

Tingkat signifikansi $(\alpha)$ dalam penelitian ini ialah sebesar 5\%. 
Adapun tahapan-tahapan dari metode Error Correction Mechanism ialah sebagai berikut:

1. Pengujian Stasioneritas Data

Pengujian stasioneritas data dalam penelitian ini menggunakan uji Augmented Dickey-Fuller yang mana menurut Ariefianto (2012), pengujian ini dilakukan dengan menghitung nilai $\tau$-statistik dengan menggunakan rumus sebagai berikut:

$\tau=\frac{\hat{\rho}}{\operatorname{Se}(\hat{\rho})}$

Adapun hipotesis yang digunakan ialah sebagai berikut:

$H_{0}: \gamma=0$

$H_{1}: \gamma<0$

Di mana: $\gamma$ merupakan simbol dari nilai stastistik MacKinnon ( $\tau$-statistik).

Keputusan: Tolak $H_{0}$ jika p-value $<\alpha$ yang berarti bahwa data telah stasioner.

Jika variabel belum stasioner pada tingkat level, maka data tersebut dilakukan diferensiasi sehingga data diuji kestasionerannya pada tingkat first difference.

2. Regresi Jangka Panjang

Menurut Juanda dan Junaidi (2012), regresi jangka panjang dilakukan dengan meregresikan variabel independen terhadap variabel dependen yang mana variabel-variabel yang akan diregresikan merupakan variabel yang belum stasioner baik pada tingkat level maupaun tingkat first difference. Persamaan regresi jangka panjang yang akan diperoleh ialah sebagai berikut:

$L P E_{t}=\beta_{0}+\beta_{1} P H M D_{t}+\beta_{2} P M D_{t}+\beta_{3} P K E T_{t}+\beta_{4} P M T B_{t}+\beta_{5} T P A K_{t}+\beta_{6} K U R S_{t}+\beta_{7} S B_{t}+\varepsilon_{t}$

3. Pengujian Kointegrasi

Menurut Ariefianto (2012), pengujian kointegrasi dilakukan pada residual hasil persamaan regresi jangka panjang yang dinamakan error correction term (ECT). Syarat pada metode ECM untuk pengujian kointegrasi ialah ECT harus stasioner pada tingkat level sehingga dilakukan uji Augmented Dickey-Fuller (uji stasioneritas data) pada ECT. Adapun hipotesis dalam pengujian ini ialah sebagai berikut;

$H_{0}: \gamma=0 ; E C T \sim \mathrm{I}(1)$

$H_{1}: \gamma<0 ; E C T \sim \mathrm{I}(0)$

Dimana: $\gamma=$ simbol dari nilai stastistik MacKinnon ( $\tau$-statistik)

$\widehat{e_{t}}=$ estimasi error hasil regresi jangka panjang (residual hasil regresi jangka panjang)

Keputusan: Tolak $H_{0}$ jika p-value $<\alpha$ yang berarti bahwa ECT stasioner pada tingkat level sehingga telah terjadi kointegrasi yang memiliki arti bahwa telah terjadi keseimbangan antara model regresi jangka panjang dan model regresi jangka pendek.

4. Regresi Jangka Pendek (Metode ECM)

Menurut Juanda dan Junaidi (2012), egresi jangka pendek dilakukan dengan meregresikan variabel independen dan ECT lag 1 yang telah stasioner pada tingkat level terhadap variabel dependen yang mana variabel-variabel yang akan diregresikan merupakan variabel yang telah didiferensiasi pada tingkat pertama. Persamaan regresi jangka pendek yang akan diperoleh ialah sebagai berikut:

$\Delta L P E_{t}=\beta_{0}+\beta_{1} \Delta P H M D_{t}+\beta_{2} \Delta P M D_{t}+\beta_{3} \Delta P K E T_{t}+\beta_{4} \Delta P M T B_{t}+\beta_{5} \Delta T P A K_{t}+\beta_{6} \Delta K U R S_{t}+$ $\beta_{7} \Delta S B_{t}+\beta_{8} \varepsilon_{t-1}+\varepsilon_{t}$

5. Pengujian Hipotesis

Pengujian hipotesis yang dilakukan dalam penelitian ini terdiri atas Uji Simultan, Uji Parsial, dan Koefisien Determinasi. Adapun penjelasan dari masing-masing pengujian hipotesis tersebut ialah berikut:

a. Uji Simultan

Menurut Bawono dan Shina (2018), Uji simultan ini digunakan untuk mengetahui apakah variabelvariabel independen secara serentak berpengaruh terhadap variabel dependen pada regresi jangka panjang dan regresi jangka pendek. Adapun hipotesis yang akan diuji ialah sebagai berikut:

$H_{o}: \beta_{1}=\beta_{2}=\cdots=\beta_{k}=0$ (Model regresi jangka pendek tidak cocok atau variabel independen secara serentak tidak berpengaruh signifikan terhadap variabel dependen)

$H_{1}$ : minimal ada satu $\beta_{i} \neq 0$ dengan $\mathrm{i}=1,2,3,4,5,6,7,8$ (Minimal terdapat satu variabel yang berpengaruh signifikan terhadap variabel dependen)

Adapun statistik uji yang digunakan dalam uji simultan ini ialah sebagai berikut:

$$
F_{\text {hitung }}=\frac{\frac{J K R}{k}}{\frac{J K G}{n-k-1}} \text {. }
$$

Dimana: JKR = Jumlah Kuadrat Regresi (Sum Squares of Regression)

$\mathrm{JKG}=$ Jumlah Kuadrat Galat (Sum Squares of Error)

$\mathrm{k}=$ banyaknya variabel bebas dalam penelitian 
$\mathrm{n}=$ banyaknya jumlah observasi dalam penelitian

Keputusan: Tolak $H_{o}$ jika p-value $<\alpha$ yang berarti bahwa minimal terdaat satu variabel independen yang berpengaruh signifikan terhadap variabel dependen.

b. Uji Parsial

Menurut Bawono dan Shina (2018), Uji parsial dilakukan untuk mengetahui apakah variabel independen ke-j memberikan pengaruh signifikan terhadap variabel dependen atau tidak. Uji parsial dalam penelitian ini akan dilakukan sebanyak 15 kali yang terdiri atas 7 uji parsial pada regresi jangka panjang dan 8 uji parsial pada regresi jangka pendek dikarenakan adanya variabel error correction term (ECT). Adapun hipotesis yang akan diuji sebagai berikut:

$H_{o}: \beta_{i}=0$ (variabel independen ke-i tidak berpengaruh signifikan terhadap variabel dependen)

$H_{1}: \beta_{i} \neq 0$ dengan $\mathrm{i}=1,2,3,4,5,6,7,8$ (variabel independen ke-i berpengaruh signifikan terhadap variabel dependen)

Adapun statistik uji yang digunakan dalam uji parsial ini ialah sebagai berikut:

$$
t_{\text {hitung }}=\frac{b_{i}}{s\left(b_{i}\right)} \ldots
$$

Dimana: $b_{i}=$ koefisien regresi variabel independen ke-i

$s\left(b_{i}\right)=$ standar error variabel independen ke-i

Keputusan: Tolak $H_{o}$ jika p-value $<\alpha$ yang berarti variabel independen ke-j berpengaruh signifikan terhadap variabel dependen.

c. Koefisien Determinasi

Menurut Bawono dan Shina (2018), Koefisien Determinasi menggambarkan seberapa besar variabel independen dapat dijelaskan dalam model. Nilai $R^{2}$ berkisar antara 0 sampai 1 dan selalu bernilai positif. Semakin besar nilai koefisien determinasi, maka semakin besar variabel independen yang dijelaskan dalam model. Adapun rumus dari $R^{2}$ ialah sebagai berikut:

$$
R^{2}=\frac{J K R}{J K T}
$$

Dimana: $R^{2}=$ koefisien determinasi

JKR = Jumlah Kuadrat Regresi (Sum Squares of Regression)

JKT = Jumlah Kuadrat Total (Sum Squares of Total)

6. Pengujian Asumsi Klasik

Pengujian asumsi klasik yang dilakukan dalam penelitian ini ialah pengujian asumsi Nonmultikolinieritas, Normalitas, Linieritas, Homoskedastisitas, dan Nonautokorelasi. Adapun penjelasan dari masing-masing pengujian asumsi tersebut ialah sebagai berikut:

a. Nonmultikolinieritas

Menurut Bawono dan Shina (2018), pengujian asumsi nonmultikolinieritas dilakukan pada masingmasing variabel independen yang digunakan dalam penelitian. Pengujian asumsi nonmultikolinieritas dilakukan dengan melihat nilai VIF (Variance Inflation Factor) masing-masing variabel independen. Suatu variabel independen ke-i dikatakan memenuhi asumsi nonmultikolinieritas jika nilai VIF $<10$.

b. Normalitas

Menurut Gujarati (2004), pengujian asumsi normalitas dilakukan untuk mengetahui apakah model ECM yang telah dihasilkan memiliki residual yang berdistribusi normal atau tidak. Pengujian asumsi normalitas dilakukan dengan menggunakan uji Jarque-Bera. Adapun hipotesis dalam uji Jarque-Bera ialah sebagai berikut:

$H_{0}: \varepsilon_{t} \sim \mathrm{N}\left(0, \sigma^{2}\right)$ (residual berdistribusi normal)

$H_{1}: \varepsilon_{t} \times \mathrm{N}\left(0, \sigma^{2}\right)$ (residual tidak berdistribusi normal)

Adapun statistik uji yang digunakan dalam uji Jarque-Bera ini ialah sebagai berikut:

$J B=\frac{n}{6}\left(S^{2}+\frac{(K-3)^{2}}{4}\right)$

Dengan:

$S=\frac{\frac{1}{n} \sum_{i=1}^{n}\left(x_{i}-\underline{x}\right)^{3}}{\left(\frac{1}{n} \sum_{i=1}^{n}\left(x_{i}-\underline{x}^{2}\right)\right)^{\frac{3}{2}}}$.

$K=\frac{\frac{1}{n} \sum_{i=1}^{n}\left(x_{i}-\underline{x}\right)^{4}}{\left(\frac{1}{n} \sum_{i=1}^{n}\left(x_{i}-\underline{x}^{2}\right)\right)^{2}}$

Dimana: JB = statistik uji Jarque-Bera

$\mathrm{S}=$ Skewness $=$ ukuran kemencengan

$\mathrm{K}=$ Kurtosis $=$ ukuran keruncingan 
Keputusan: Gagal Tolak $H_{o}$ jika p-value $>\alpha$ yang berarti residual model ECM berdistribusi normal sehingga asumsi normalitas terpenuhi.

c. Linieritas

Menurut Gujarati (2004), pengujian asumsi linieritas dilakukan untuk mengetahui apakah model regresi yang terbentuk merupakan model linier atau tidak. Pengujian asumsi linieritas dilakukan dengan menggunakan uji Ramsey RESET. Adapun hipotesis dalam uji Ramsey RESET ialah sebagai berikut:

$H_{0}$ : Model regresi jangka pendek (ECM) yang terbentuk merupakan model linier

$H_{1}$ : Model regresi jangka pendek (ECM) yang terbentuk bukan merupakan model linier.

Adapun statistik uji yang digunakan dalam uji Ramsey RESET ialah sebagai berikut:

$F_{\text {hitung }}=$

$$
R_{\text {baru }}^{2}-R_{\text {lama }}^{2}
$$

$\overline{\text { jumlah variabel baru yang masuk }}$

$\left(1-R_{\text {baru }}^{2}\right) /(n-$ banyaknya parameter dalam persamaan baru

Dimana: $R_{\text {baru }}^{2}=$ koefisien determinasi pada persamaan baru

$R_{\text {lama }}^{2}=$ koefisien determinasi pada persamaan lama

Keputusan: Gagal Tolak $H_{o}$ jika p-value $>\alpha$ yang berarti model ECM merupakan model linier sehingga asumsi linieritas terpenuhi.

d. Homoskedastisitas

Menurut Gujarati (2004), pengujian asumsi homoskedastisitas dilakukan untuk mengetahui apakah varians dari error bersifat konstan atau tidak. Pengujian asumsi homoskedatisitas dilakukan dengan menggunakan uji Breusch-Pagan-Godfrey. Adapun hipotesis dalam uji Breusch-Pagan-Godfrey ialah sebagai berikut:

$H_{0}: \operatorname{var}(X)=E(X)=\sigma^{2}$ (terjadi homoskedastisitas)

$H_{1}: \operatorname{var}(X)=\sigma_{i}^{2}$ (terjadi heteroskedastisitas)

Adapun statistik uji yang digunakan dalam uji Breusch-Pagan-Godfrey ialah sebagai berikut:

$\mathrm{LM}=32 \cdot R_{\varepsilon_{t}^{2}}^{2}$

Dimana: $\mathrm{LM}=$ statistik uji Lagrange Multiplier

$R_{\varepsilon_{t}^{2}}^{2}=$ koefisien determinasi hasil regresi variabel independen dan residual kuadrat terhadap variabel dependen

Keputusan: Gagal Tolak $H_{O}$ jika p-value $>\alpha$ yang berarti varians error bersifat konstan sehingga asumsi homoskedastisitas terpenuhi.

e. Nonautokorelasi

Menurut Gujarati (2004), pengujian asumsi nonautokorelasi dilakukan untuk mengetahui apakah terjadi autokorelasi pada model ECM atau tidak. Pengujian asumsi nonautokorelasi dilakukan dengan menggunakan uji Breusch-Godfrey. Adapun hipotesis dalam uji Breusch-Godfrey ialah sebagai berikut: $H_{0}: \rho_{1}=\rho_{2}=\rho_{3}=\rho_{4}=\rho_{5}=\rho_{6}=\rho_{7}=\rho_{8}=0$ (tidak terjadi autokorelasi dalam model)

$H_{1}$ : minimal ada satu $\rho_{i}=0, i=1,2,3,4,5,6,7,8$ (terjadi autokorelasi dalam model)

Dimana: $\rho=$ koefisien autokorelasi

Adapun statistik uji yang digunakan dalam uji Breusch-Godfrey ialah sebagai berikut:

$B G_{\text {hitung }}=22\left(R^{2}\right)$

Dimana: $R^{2}=$ koefisien determinasi

Keputusan: Gagal Tolak $H_{o}$ jika p-value $>\alpha$ yang berarti tidak terjadi autokorelasi dalam model ECM sehingga asumsi nonautkorelasi terpenuhi.

\section{Data dan Sumber Data}

Penelitian ini berfokus di Indonesia dengan periode waktu mulai dari tahun 1987 hingga tahun 2019. Penelitian ini bertujuan untuk mengetahui faktor-faktor apa saja yang berpengaruh terhadap pertumbuhan ekonomi dilihat dari sisi energi, faktor produksi, dan kebijakan moneter. Penelitian ini terdiri atas 1 (satu) variabel dependen dan 7 (tujuh) variabel independen. Data-data (variabel-variabel dikumpulkan secara sekunder dari website-website dan publikasi beberapa lembaga dan instansi pemerintahan mulai dari tahun 1987 hingga tahun 2019. Berikut tabel ringkasan variabel-variabel yang digunakan dalam penelitian ini: 
Tabel 1. Ringkasan Variabel Penelitian

\begin{tabular}{|c|c|c|c|c|c|}
\hline No. & $\begin{array}{l}\text { Nama Variabel dan } \\
\text { Penamaan }\end{array}$ & $\begin{array}{c}\text { Jenis } \\
\text { Variabel }\end{array}$ & Definisi & $\begin{array}{c}\text { Sumber } \\
\text { Referensi }\end{array}$ & Sumber Data \\
\hline 1 & $\begin{array}{l}\text { Laju Pertumbuhan } \\
\text { Ekonomi (LPE) }\end{array}$ & $\begin{array}{l}\text { Variabel } \\
\text { Dependen }\end{array}$ & $\begin{array}{l}\text { Selisih total PDB pengeluaran } \\
\text { tahun } \\
\text { sekarang dengan total PDB } \\
\text { pengeluaran tahun sebelumnya }\end{array}$ & Putra (2016) & $\begin{array}{c}\text { Badan Pusat } \\
\text { Statisik RI }\end{array}$ \\
\hline 2 & $\begin{array}{l}\text { Harga Minyak } \\
\text { Dunia (PHMD) }\end{array}$ & $\begin{array}{l}\text { Variabel } \\
\text { Independen }\end{array}$ & $\begin{array}{l}\text { Selisih harga minyak periode } \\
\text { sekarang dengan harga minyak } \\
\text { periode sebelumnya }\end{array}$ & $\begin{array}{l}\text { Dwi dkk } \\
\text { (2016); } \\
\text { Sultan dkk } \\
\quad(2019)\end{array}$ & Ourworldindata.org \\
\hline 3 & $\begin{array}{l}\text { Produksi Minyak } \\
\text { Dunia (PMD) }\end{array}$ & $\begin{array}{l}\text { Variabel } \\
\text { Independen }\end{array}$ & Jumlah produksi minyak dunia & $\begin{array}{l}\text { Djelloul dan } \\
\text { Talbi (2017); } \\
\text { Gorus } \\
\text { (2017) }\end{array}$ & Ourworldindata.org \\
\hline 4 & $\begin{array}{l}\text { Konsumsi Energi } \\
\text { Terbarukan } \\
\text { Indonesia } \\
\text { (PKET) }\end{array}$ & $\begin{array}{l}\text { Variabel } \\
\text { Independen }\end{array}$ & $\begin{array}{c}\text { Persentase konsumsi energi } \\
\text { terbarukan terhadap jumlah } \\
\text { konsumsi energi primer di } \\
\text { Indonesia }\end{array}$ & $\begin{array}{l}\text { Can dan } \\
\text { Korkmaz } \\
(2017)\end{array}$ & Ourworldindata.org \\
\hline 5 & $\begin{array}{l}\text { Pembentukan } \\
\text { Modal Tetap Bruto } \\
\text { (PMTB) }\end{array}$ & $\begin{array}{l}\text { Variabel } \\
\text { Independen }\end{array}$ & $\begin{array}{l}\text { Persentase PMTB terhadap } \\
\text { PDB Pengeluaran }\end{array}$ & $\begin{array}{l}\text { Sarwar et al. } \\
\text { (2017); } \\
\text { Gulzar Ali } \\
\text { (2017) }\end{array}$ & $\begin{array}{l}\text { Badan Pusat } \\
\text { Statistik RI }\end{array}$ \\
\hline 6 & $\begin{array}{l}\text { Tingkatan } \\
\text { Partisipasi } \\
\text { Angkatan Kerja } \\
\text { (TPAK) }\end{array}$ & $\begin{array}{c}\text { Variabel } \\
\text { Independen }\end{array}$ & $\begin{array}{c}\text { Perbandingan antara angkatan } \\
\text { kerja dengan penduduk usia } \\
\text { kerja yang dinyatakan dalam } \\
\text { persen }\end{array}$ & $\begin{array}{l}\text { Zhao et al. } \\
\text { (2016); } \\
\text { Korkmaz et } \\
\text { al. (2017) }\end{array}$ & $\begin{array}{c}\text { Badan Pusat } \\
\text { Statistik RI }\end{array}$ \\
\hline 7 & $\begin{array}{l}\text { Nilai Tukar Rupiah } \\
\text { terhadap Dollar } \\
\text { Amerika Serikat } \\
\quad \text { (KURS) }\end{array}$ & $\begin{array}{l}\text { Variabel } \\
\text { Independen }\end{array}$ & $\begin{array}{c}\text { Harga atau nilai mata uang } \\
\text { Dollar } \\
\text { Amerika Serikat dinyatakan } \\
\text { dalam nilai mata uang Rupiah }\end{array}$ & Putra (2016) & World Bank \\
\hline 8 & Suku Bunga (SB) & $\begin{array}{l}\text { Variabel } \\
\text { Independen }\end{array}$ & $\begin{array}{c}\text { Nilai, tingkat, harga atau } \\
\text { keuntungan yang diberikan } \\
\text { kepada investor dari } \\
\text { penggunaan } \\
\text { dana investasi atas dasar } \\
\text { perhitungan nilai ekonomis } \\
\text { dalam periode waktu tertentu }\end{array}$ & $\begin{array}{l}\text { Saputri } \\
(2018)\end{array}$ & World Bank \\
\hline
\end{tabular}

\section{HASIL DAN PEMBAHASAN}

\section{Gambaran Umum Laju Pertumbuhan}

Pertumbuhan ekonomi merupakan salah satu indikator yang bisa digunakan untuk mengetahui kesejahteraan masyarakat dan perkembangannya dalam suatu negara. Pertumbuhan ekonomi bisa dilihat dari Produk Domestik Bruto (PDB). Dengan kata lain, Produk Domestik Bruto (PDB) dapat digunakan untuk melihat laju pertumbuhan ekonomi dalam sebuah negara.

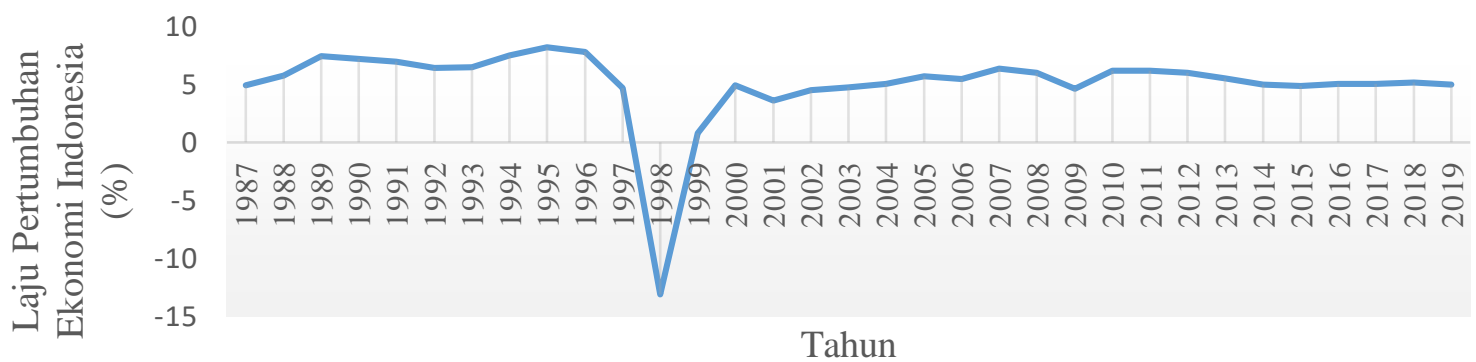

Sumber: Badan Pusat Statistik RI (diolah)

Gambar 1. Laju Pertumbuhan Ekonomi Indonesia tahun 1987-2019 
Secara keseluruhan, laju pertumbuhan ekonomi Indonesia berfluktuasi dari tahun ke tahun. Pada tahun 1987, laju pertumbuhan ekonomi Indonesia sebesar 4,92\% dan mengalami peningkatan hingga tahun 1995. Laju pertumbuhan ekonomi Indonesia tertinggi pada tahun 1995 yaitu sebesar 8,22\%. Hal ini bisa saja disebabkan karena sumber pertumbuhan ekonomi pada saat itu didominasi oleh produksi dalam negeri dibandingkan produksi luar negeri sehingga bisa dikatakan bahwa negara bisa mengendalikan harga dalam negeri dan hal tersebutlah yang menyebabkan masyarakat lebih cenderung minat pada produksi dalam negeri dibanding produksi dalam negeri. Kemudian, pada tahun 1996 hingga tahun 1998, laju pertumbuhan ekonomi Indonesia cenderung mengalami penurunan hingga pada tahun 1998, Indonesia mengalami krisis finansial Asia atau biasa disebut sebagai krisis moneter sehingga menyebabkan laju pertumbuhan ekonomi Indonesia berada dalam titik paling rendah dalam 25 tahun terakhir, yaitu sebesar $-13,12 \%$. Keadaan Indonesia yang saat itu kurang stabil menyebabkan situasi/kondisi/keadaan perekonomian di negara Indonesia juga tidak stabil sehingga membuat barang-barang kebutuhan hidup menjadi langka dan mahal harganya. Keadaan perekonomian Indonesia yang tidak stabil inilah yang menyebabkan Indonesia mengalami perekonomian terburuk sepanjang sejarah. Kemudian pada tahun 1999, laju pertumbuhan ekonomi di Indonesia mulai meningkat sehingga laju pertumbuhan ekonomi di Indonesia pada tahun 1999 menjadi sebesar 0,79\%. Kemudian, mulai tahun 1999 hingga tahun 2019, laju pertumbuhan ekonomi di Indonesia cenderung mengalami peningkatan. Hal ini dikarenakan produksi barang dan jasa di Indonesia sudah mulai disesuaikan dengan kebutuhan warga negaranya sehingga kondisi perekonomian di Indonesia bisa dikatakan stabil.

\section{Hasil Estimasi Metode Error Correction Mechanism}

Setelah melihat perkembangan laju pertumbuhan ekonomi dan faktor-faktor yang memengaruhinya, maka akan dilihat bagaimana faktor-faktor yang telah dijelaskan di atas bisa memengaruhi laju pertumbuhan ekonomi di Indonesia. Untuk melihat hal tersebut, penelitian ini menggunakan metode Error Correction Mechanism. Adapun hasil estimasinya ialah sebagai berikut:

\subsection{Uji Stasioneritas Data}

Hasil uji stasioneritas data pada penelitian ini dapat dilihat pada tabel berikut:

Tabel 2. Hasil Uji Augmented Dickey-Fuller pada tingkat Level dan tingkat First Difference

\begin{tabular}{|c|c|c|c|c|c|}
\hline \multirow{2}{*}{$\begin{array}{l}\text { No } \\
\text {. }\end{array}$} & \multirow[t]{2}{*}{ Variabel } & \multicolumn{2}{|c|}{ Tingkat Level } & \multicolumn{2}{|c|}{ Tingkat First Difference } \\
\hline & & p-value & Keterangan & p-value & Keterangan \\
\hline 1 & LPE & 0,0045 & Stasioner & 0,0000 & Stasioner \\
\hline 2 & PHMD & 0,0001 & Stasioner & 0,0008 & Stasioner \\
\hline 3 & PMD & 0,8730 & Belum Stasioner & 0,0000 & Stasioner \\
\hline 4 & PKET & 0,0023 & Stasioner & 0,0021 & Stasioner \\
\hline 5 & РMTB & 0,0499 & Stasioner & 0,0002 & Stasioner \\
\hline 6 & TPAK & 0,0881 & Belum Stasioner & 0,0000 & Stasioner \\
\hline 7 & KURS & 0,7668 & Belum Stasioner & 0,0000 & Stasioner \\
\hline 8 & SB & 0,0001 & Stasioner & 0,0000 & Stasioner \\
\hline
\end{tabular}

Sumber: Output EViews (diolah)

Dari tabel di atas, kita bisa melihat terdapat 5 variabel yang stasioner pada tingkat level, yaitu laju pertumbuhan ekonomi, perubahan harga minyak dunia, persentase konsumsi energi terbarukan terhadap total konsumsi energi di Indonesia, persentase pembentukan modal tetap bruto terhadap total PDB pengeluaran Indonesia, dan suku bunga.Selain itu, terdapat 3 variabel yang stasioner pada tingkat first difference, yaitu produksi minyak dunia, tingkat partisipasi angkatan kerja, dan nilai tukar Rupiah terhadap Dollar Amerika Serikat.

1.2 Regresi Jangka Panjang

Hasil estimasi persamaan regresi jangka panjang dalam penelitian ini bisa dilihat pada tabel berikut: 
Tabel 3. Hasil Estimasi Persamaan Regresi Jangka Panjang

\begin{tabular}{cccccc}
\hline No. & Variabel & Koefisien & $\begin{array}{l}\text { Standard } \\
\text { Error }\end{array}$ & t-Statistik & p-value (probabilitas) \\
\hline 1 & C & $-60,5463$ & 45,5772 & $-1,3284$ & 0,1960 \\
2 & PHMD & 0,0223 & 0,0189 & 1,1808 & 0,2488 \\
3 & PMD & 0,0011 & 0,0004 & 3,1227 & $0,0045^{*}$ \\
4 & PKET & 1,8547 & 2,6494 & 0,7000 & 0,4904 \\
5 & PMTB & $-0,2461$ & 0,2806 & $-0,8770$ & 0,3888 \\
6 & TPAK & 0,4433 & 0,6264 & 0,7078 & 0,4856 \\
7 & KURS & $-0,0014$ & 0,0005 & $-3,1486$ & $0,0042^{*}$ \\
8 & SB & 0,2568 & 0,0542 & 4,7345 & $0,0001^{*}$ \\
& R-squared & 0,7639 & & F-Statistik & 11,5557 \\
& Adjusted R-squared & 0,6978 & & p-value & 0,0000 \\
& & & & & \\
\hline
\end{tabular}

Sumber: Output EViews (diolah)

Keterangan: *) signifikan pada $\alpha=5 \%$

Adapun model persamaan regresi jangka panjang dalam penelitian ini dapat dituliskan sebagai berikut:

$\widehat{L P E_{t}}=-60,5463+0,0223 P H M D_{t}+0,0011 P M D_{t}^{*}+1,8547 P K E T_{t}-0,2461 P M T B_{t}+$

$0,4433 T P A K_{t}-0,0015 K U R S_{t}^{*}+0,2568 S B_{t}^{*}$.

Setelah didapatkan hasil estimasi persamaan regresi jangka panjangnya, maka akan dilakukan uji simultan dan uji parsial untuk melihat bagaimana pengaruh variabel-variabel penelitian ini dalam jangka panjang. Uji simultan dilakukan dengan menggunakan uji F. Hasil uji F didapatkan bahwa p-value sebesar 0,000 yang mana p-value $<\alpha$ sehingga Tolak $H_{0}$ yang menandakan bahwa kita memiliki cukup bukti untuk mengatakan bahwa terdapat minimal satu variabel independen yang berpengaruh signifikan terhadap laju pertumbuhan ekonomi Indonesia dalam jangka panjang.

Uji parsial dilakukan dengan uji t. Hasil uji t yang didapatkan ialah terdapat 3 variabel yang memiliki pvalue $<\alpha$. Hasil uji t yang didapatkan ialah hanya terdapat 3 variabel yang berpengaruh signifikan terhadap laju pertumbuhan ekonomi di Indonesia tahun 1987-2019 dalam jangka panjang, yaitu produksi minyak dunia, nilai tukar Rupiah terhadap Dollar Amerika Serikat, dan suku bunga.

Berdasarkan hasil estimasi persamaan regresi jangka panjang, terdapat 3 variabel yang signifikan terhadap laju pertumbuhan ekonomi Indonesia tahun 1987-2019 dalam jangka panjang, yaitu produksi minyak dunia, nilai tukar Rupiah terhadap Dollar Amerika Serikat, dan suku bunga. Signifikannya produksi minyak dunia sejalan dengan penelitian yang dilakukan oleh Djelloul dan Talbi (2017). Hal ini dikarenakan adanya ketergantungan sumber energi minyak bumi yang digunakan oleh hampir seluruh kegiatan produksi barang dan jasa yang dilakukan di Indonesia ini. Minyak bumi digunakan sebagai bahan bakar alat-alat produksi, bahan bakar untuk alat transportasi, dan lain sebagainya. Oleh karena itu, Indonesia masih memiliki ketergantungan besar terhadap minyak bumi. Adanya ketergantungan pada minyak bumi ini bisa membuat kegiatan produksi barang dan jasa di negara kita tergantung pada persediaan minyak bumi. Signifikannya nilai tukar Rupiah terhadap Dolla Amerika Serikat sejalan dengan penelitian yang dilakukan oleh Putra (2016). Hal ini dikarenakan Secara jangka panjang, nilai tukar Rupiah ke Dollar Amerika Serikat ini biasanya ditentukan oleh kebijakan pemerintah untuk menjaga keseimbangan nilai tukar tersebut. Dengan adanya keseimbangan nilai tukar Rupiah ke Dollar Amerika Serikat, maka hal ini juga bisa memiliki pengaruh pada laju pertumbuhan ekonomi di Indonesia. Signifikannya suku bunga sejalan dengan penelitian yang dilakukan oleh Saputri (2018). Hal ini dikarenakan banyak modal asing yang masuk ke dalam negeri sehingga bisa membuat kegiatan perekonomian berjalan lancar dan membuat laju pertumbuhan ekonomi Indonesia menjadi lebih baik.

1.3 Pengujian Kointegrasi

Hasil pengujian kointegrasi bisa diketahui dari uji Augmented Dickey-Fuller pada ECT. Adapun tingkat signifikansi $(\alpha)$ yang digunakan ialah sebesar $5 \%$. Hasil yang didapatkan ialah variabel ECT memiliki p-value sebesar 0,0012 yang berarti bahwa p-value $<\alpha$ sehingga ECT stasioner pada tingkat level. Hal ini menandakan bahwa telah terjadi kointegrasi atau telah terjadi keseimbangan antara model regresi jangka panjang dan model regresi jangka pendek.

1.4 Regresi Jangka Pendek

Hasil estimasi persamaan regresi jangka pendek dalam penelitian ini bisa dilihat pada tabel berikut: 
Tabel 4. Hasil Estimasi Regresi Jangka Pendek

\begin{tabular}{cccccc}
\hline No. & Variabel & Koefisien & Standard Error & t-Statistik & p-value (probabilitas) \\
\hline 1 & C & 0,3390 & 0,3213 & 1,0551 & 0,3024 \\
2 & D(PHMD) & 0,0196 & 0,0099 & 1,9651 & 0,0616 \\
3 & D(PMD) & 0,0001 & 0,0004 & 0,2655 & 0,7930 \\
4 & D(PKET) & 1,3542 & 1,8807 & 0,7200 & 0,4788 \\
5 & D(PMTB) & 0,5273 & 0,2010 & 2,6227 & $0,0152^{*}$ \\
6 & D(TPAK) & 0,2264 & 0,4218 & 0,5367 & 0,5966 \\
7 & D(KURS) & $-0,0012$ & 0,0003 & $-3,5731$ & $0,0016^{*}$ \\
8 & D(SB) & 0,2138 & 0,0366 & 5,8354 & $0,0000^{*}$ \\
9 & ECT(-1) & $-0,8388$ & 0,1512 & $-5,5482$ & $0,0000^{*}$ \\
& R-squared & 0,9288 & & F-stastistik & 37,4968 \\
& Adjusted R-squared & 0,9040 & & p-value & 0,0000 \\
& & & (probabilitas) & \\
\hline
\end{tabular}

Sumber: Output EViews (diolah)

Keterangan: *) signifkan pada $\alpha=5 \%$

Adapun model persamaan regresi jangka pendeknya dapat dituliskan sebagai berikut:

$\Delta \widehat{L P E_{t}}=0,3390+0,0196 \Delta P H M D_{t}+0,00013 \Delta P M D_{t}+1,3542 \Delta P K E T_{t}+0,5273 \Delta P M T B_{t}^{*}+$

$0,2264 \Delta T P A K_{t}-0,0012 \Delta K U R S_{t}^{*}+0,2138 \Delta S B_{t}^{*}-$

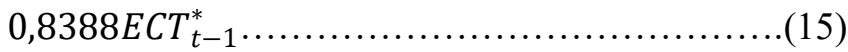

Persamaan di atas menunjukkan hasil estimasi persamaan regresi jangka pendek. Setelah didapatkan hasil estimasi persamaan regresi jangka pendeknya, maka kita perlu melakukan uji simultan dan uji parsial untuk melihat bagaimana pengaruh variabel-variabel penelitian ini dalam jangka pendek. Uji simultan dilakukan dengan menggunakan uji F. Hasil uji F didapatkan bahwa p-value sebesar 0,000 yang mana p-value $<\alpha$ sehingga Tolak $H_{0}$ yang menandakan bahwa kita memiliki cukup bukti untuk mengatakan bahwa minimal terdapat satu variabel independen yang berpengaruh terhadap laju pertumbuhan ekonomi di Indonesia dalam jangka pendek.

Uji parsial dilakukan dengan uji t. Hasil uji t yang didapatkan ialah terdapat 4 variabel yang berpengaruh signifikan terhadap laju pertumbuhan ekonomi di Indonesia tahun 1987-2019 dalam jangka pendek, yaitu persentase pembentukan modal tetap bruto terahadp total PDB Pengeluaran di Indoensia, nilai tukar Rupiah terhadap Dollar Amerika Serikat, suku bunga, dan ECT. Signifikannya ECT lag 1 pada hasil regresi jangka panjang dan memiliki koefisien bertanda negatif menandakan bahwa telah terjadi kointegrasi atau telah terjadi keseimbangan antara model regresi jangka panjang dan regresi jangka pendek.

Koefisien determinasi pada hasil penelitian bisa dilihat pada nilai adjusted R-squared hasil estimasi persamaan regresi jangka pendek. Nilai adjusted R-squared dalam hasil penelitian ini sebesar 0,9040 yang memiliki arti bahwa sebanyak 90,4\% variabel perubahan harga minyak dunia, produksi minyak dunia, persentase konsumsi energi terbarukan terhadap total konsumsi energi, persentase pembentukan modal tetap bruto terhadap total PDB pengeluaran, tingkat partisipasi angkatan kerja, nilai tukar rupiah ke dollar Amerika Serikat, suku bunga, dan ECT lag 1 dapat menjelaskan keragaman variabel laju pertumbuhan ekonomi, sisanya sebesar $9,6 \%$ dijelaskan oleh variabel lain di luar model.

Berdasarkan hasil estimasi persamaan regresi jangka pendek, terdapat 4 variabel yang signifikan terhadap laju pertumbuhan ekonomi Indonesia tahun 1987-2019 dalam jangka pendek, yaitu persentase pembentukan modal tetap bruto terhadap total PDB pengeluaran Indonesia, nilai tukar Rupiah terhadap Dollar Amerika Serikat, suku bunga, dan EC Signifikannya persentase pembentukan modal tetap bruto terhadap total PDB pengeluaran Indonesia sejalan dengan penelitian yang dilakukan oleh Sarwar dkk (2017). Hal ini dikarenakan adanya dalam suatu kegiatan produksi pastinya kita membutuhkan aset aset yang diperlukan agar kegiatan produksi tersebut berjalan lancar seperti unit kegiatan produksi, alat-alat produksi, mesin-mesin produksi, dan lain sebagainya yang mana kemudian aset-aset tersebut bisa menjadi investasi bagi si pemiliknya di kemudian hari. Dengan adanya investasi, maka pendapatan negara akan semakin banyak sehingga bisa meningkatkan laju pertumbuhan ekonomi di negara Indonesia. Signifikannya nilai tukar Rupiah terhadap Dollar Amerika Serikat sejalan dengan penelitian yang dilakukan oleh Putra (2016). Hal ini dikarenakan dalam jangka pendek, nilai tukar Rupiah ke Dollar Amerika Serikat ini biasanya ditentukan oleh permintaan dan penawaran terhadap nilai tukar tersebut sehingga bisa berdampak pada laju pertumbuhan ekonomi Indonesia. Signifikannya suku bunga sejalan dengan penelitian yang dilakukan oleh Saputri (2018). Hal ini dikarenakan adanya kenaikan 
suku bunga bisa membuat modal asing masuk ke dalam negeri sehingga bisa membuat para investor menanam investasinya di negeri ini yang mana berdampak pada pembangunan-pembangunan yang ada di negeri ini.

1.5 Pengujian Asumsi Klasik

Pengujian asumsi klasik dalam penelitian ini terdiri atas 5 pengujian, yaitu pengujian asumsi nonmultikolinieritas, pengujian asumsi normalitas, pengujian asumsi linieritas, pengujian asumsi homoskedastisitas, dan pengujian asumsi nonautokorelasi yang mana setiap hasil pengujian asumsi-asumsi yang telah diringkas dalam tabel sebagai berikut:

Tabel 5. Ringkasan Hasil Pengujian Asumsi Klasik

\begin{tabular}{clll}
\hline No. & Pengujian Asumsi & \multicolumn{1}{c}{ Hasil } & \multicolumn{1}{c}{ Keputusan } \\
\hline 1 & Nonmultikolinieritas & $\begin{array}{l}\text { Semua variabel independen memiliki } \\
\text { nilai VIF kurang dari 10 }\end{array}$ & Asumsi Nonmultikolinieritas Terpenuhi \\
& & p-value sebesar 0,7199 & Asumsi Normalitas Terpenuhi \\
2 & Normalitas & p-value sebesar 0,6317 & Asumsi Linieritas Terpenuhi \\
3 & Linieritas & p-value sebesar 0,1642 & Asumsi Homoskedastisitas Terpenuhi \\
4 & Homoskedastisitas & p-value sebesar 0,7369 & Asumsi Nonautokorelasi Terpenuhi \\
5 & Nonautokorelasi & & \\
\hline
\end{tabular}

Sumber: Output EViews (diolah)

\section{KESIMPULAN}

Setelah melakukan analisis pada penelitian ini, maka kesimpulan yang dapat diambil ialah hasil penelitian yang dilakukan oleh peneliti tentang laju pertumbuhan ekonomi di Indonesia tahun 1987 hingga tahun 2019, dapat disimpulkan bahwa laju pertumbuhan ekonomi di Indonesia cenderung mengalami fluktuasi dari tahun ke tahun. Mulai dari tahun 1987, Indonesia mengalami laju pertumbuhan ekonomi yang cukup stabil hingga pada tahun 1995, laju pertumbuhan ekonomi Indonesia berada pada titik tertinggi. Setelah itu, laju pertumbuhan ekonomi di Indonesia mengalami penurunan hingga pada tahun 1998, laju pertumbuhan ekonomi Indonesia mengalami titik terendah. Setelah itu, laju pertumbuhan ekonomi Indonesia berangsur-angsur bangkit dari titik terendahnya hingga pada tahun 2019, laju pertumbuhan ekonomi Indonesia mengalami fluktuasi dari tahun ke tahun.

Berdasarkan hasil yang diperoleh, hal yang bisa diketahui ialah konsumsi energi terbarukan tidak memiliki pengaruh terhadap laju pertumbuhan ekonomi di Indonesia baik dalam jangka panjang maupun jangka pendek. Selain itu, terdapat 3 variabel yang berpengaruh terhadap laju pertumbuhan ekonomi di Indonesia tahun 1987-2019 dalam jangka panjang, yaitu produksi minyak dunia, nilai tukar Rupiah terhadap Dollar Amerika Serikat, dan suku bunga. Adapun 4 variabel yang berpengaruh terhadap laju pertumbuhan ekonomi di Indonesia tahun 1987-2019 dalam jangka pendek, yaitu persentase PMTB terhadap total PDB pengeluaran Indonesia, nilai tukar Rupiah terhadap Dollar Amerika Serikat, suku bunga, dan Error Correction Term (ECT). Oleh karena itu, negara Indonesia masih memiliki ketergantungan besar pada produksi minyak dunia pada hampir seluruh kegiatan produksi barang dan jasa yang dilakukan di negara Indonesia. Hal ini bisa dilihat pada produksi minyak dunia yang berpengaruh signifikan terhadap laju pertumbuhan ekonomi di Indonesia dalam jangka panjang. Selain itu, negara Indonesia juga masih bergantung pada investasi-investasi ataupun modal-modal dalam negeri untuk membiayai pembangunan-pembangunan di negara Indonesia. Hal ini bisa dilihat pada persentase pembentukan modal tetap bruto terhadap total PDB pengeluaran di Indonesia yang berpengaruh signifikan terhadap laju pertumbuhan ekonomi di Indonesia dalam jangka pendek. Berdasarkan hasil yang diperoleh, hal yang bisa diketahui ialah perekonomian negara Indonesia lebih didominasi oleh sektor moneter, khususnya nilai tukar Rupiah ke Dollar Amerika Serikat dan suku bunga. Hal ini bisa dilihat pada nilai tukar Rupiah ke Dollar Amerika Serikat dan suku bunga yang berpengaruh signifikan terhadap laju pertumbuhan ekonomi baik dalam jangka panjang maupun jangka pendek.

\section{UCAPAN TERIMA KASIH}

Kami ucapkan terima kasih kepada Politeknik Statistiks STIS atas sarana dan prasarana yang disediakan sehingga penelitian ini dapat berjalan dengan baik. 


\section{DAFTAR PUSTAKA}

Ali, Gulzar. (2017). Gross Fixed Capital Formation and Economic Growth of Pakistan. IMPACT: Journal of Research in Humanities, Arts, and Literature. Volume 1. pp 21-30. Diakses pada 23 November 2020 dari https://www.impactjournals.us/download/archives/--1501070271-4.humGROSS\%20FIXED\%20CAPITAL\%20FORMATION\%20\%20ECONOMIC\%20GROWTH.pdf

Ariefianto, Doddy. (2012). Ekonometrika ( Esensi dan Aplikasi dengan Menggunakan EViews ). Jakarta: Erlangga.

Bawono, A., Shina, A. (2018). Ekonometrika Terapan Untuk Ekonomi dan Bisnis Islam (Aplikasi dengan Eviews). Salatiga: Lembaga Penelitian dan Pengabdian kepada Masyarakat IAIN Salatiga.

Can dan Korkmaz. (2017). The relationship between renewable consumption and economic growth (the case of Bulgaria). International Jurnal of Energy Sector Management. Volume 13. pp 573-599. Doi: https://doi.org/10.1108/IJESM-11-2017-0005

Djelloul, B., Talbi, B. (2017). The Impact of Oil Production on Economic Growth in OPEC Countries: Evidence From The Panel Approach. The Journal of Applied Business Research. Volume 33. pp 257262. Doi: https://doi.org/10.19030/jabr.v33i2.9897

Dwi dkk. (2016). Pengaruh Harga Minyak Dunia, Inflasi, dan Nilai Tukar terhadap Pertumbuhan Ekonomi Indonesia (Studi pada tahun 2007-2014). Jurnal Administrasi Bisnis Universitas Sriwijaya. Volume 40. $\begin{array}{llllll}\text { Halaman } & 130-138 . & \text { Diakses pada } 31 & \text { Oktober } 2020 & \text { dari }\end{array}$ http://administrasibisnis.studentjournal.ub.ac.id/index.php/jab/article/view/1616

Gorus, M., S. (2017). Oil Production-Economic Growth Nexus in Saudi Arabia: ARDL Bound and Bootstrap Causality Test. The Empirical Economic Letters. Volume 16. pp 889-897. Diakses pada 24 November 2020 dari https://www.researchgate.net/publication/321049662_Oil_ProductionEconomic Growth Nexus in Saudi Arabia ARDL Bound and Bootstrap Causality Test

Gujarati, Damodar N. (2004). Basic Econometrics Fourth Edition. United States: The McGraw-Hill Companies.

Juanda, B., Junaidi. (2012). Ekonometrika Deret Waktu. Bogor: PT Penerbit IPB Press.

Korkmaz, S., Korkmaz, O. (2017). The Relationship Between Labor Productivity and Economic Growth in OECD Countries. International Journal of Economics and Finance. Volume 9. pp 71-76. Doi: https://doi.org/10.5539/ijef.v9n5p71

Mankiw, Gregory N.. (2003). Teori Makroekonomi (Edisi Kelima). Jakarta: Erlangga.

Nopirin. (2018). Ekonomi Moneter Buku II (Edisi Pertama). Yogyakarta: BPFE Yogyakarta.

Putra, Hendra Eka. (2016). Pengaruh Harga Minyak Dunia, Nilai Tukar Rupiah, Pengeluaran Pemerintah terhadap Pertumbuhan Ekonomi di Indonesia tahun 1985-2014. Perpustakaan Universitas Airlangga. Diakses pada 30 Oktober 2020 dari http://repository.unair.ac.id/53078/

Rudiansyah. (2013). Sistem Neraca Nasional 2008. Jakarta:Badan Pusat Statistik.

Saputri, Riski Nanda. (2018). Pengaruh Indeks Harga Konsumen, Kurs, dan Suku Bunga terhadap Pertumbuhan Ekonomi di Indonesia Periode Tahun 1999-2015. Universitas Muhammadiyah Surakarta. Diakses pada 29 Maret 2021 dari http://eprints.ums.ac.id/61195/11/NASKAH\%20PUBLIKASI-282.pdf

Sarwar dkk (2017). Electricity Consumption, Oil Price, and Economic Growth: Global Perspective. Elsevier. Volume 76. pp 9-18. Doi: http://dx.doi.org/10.1016/j.rser.2017.03.063

Sukirno, Sadono. (2016). Makroekonomi Teori Pengantar (Edisi Ketiga). Jakarta: PT RajaGrafindo Persada.

Sultan dkk (2019). Oil Price and Indonesia Economic Growth. Problems and Perspectives in Management Journal. Volume 17. pp 152-162. Doi:

Zhao dkk (2016). Economic Growth, Electricity Consumption, Labor Force and Capital Input: A More Comprehensive Analysis on North China Using Panel Data. MDPI. Volume 9. pp 1-21. Doi: https://doi.org/10.3390/en9110891 